\title{
Redescription of trematode Gonocerca muraenolepisi Paruchin et Ljadov, 1979 (Hemiuroidea: Derogenidae), a body cavity parasite of Antarctic fishes, with a discussion of its phylogenetic position
}

\author{
S.G. Sokolov', I.I. Gordeev², D.M. Atopkin ${ }^{3}$ \\ ${ }^{1}$ A.N. Severtsov Institute of Ecology and Evolution RAS, Leninskij pr-t 33, Moscow 119071, Russia. \\ e-mail:sokolovsg@mail.ru \\ ${ }^{2}$ Russian Federal Research Institute of Fisheries and Oceanography, V. Krasnoselskaya st. 17, \\ Moscow 107140, Russia. \\ ${ }^{3}$ Institute of Biology and Soil Science FEB RAS, pr-t 100-letiya Vladivostoka 159, Vladivostok \\ 690022, Russia.
}

ABSTRACT: The redescription of Gonocerca muraenolepisi Paruchin et Ljadov, 1979 was made on the specimens collected from Muraenolepis marmorata Günther, 1880 (Gadiformes), caught in the Ross Sea, and on extant paratypes - one of which was designated as neotype - is given in this paper. Phylogenetic relations of G. muraenolepisi were inferred by Bayesian analysis of partial sequences from $28 \mathrm{~S} \mathrm{rDNA}$. Molecular data are not consistent with the traditional point of view about the position of the genus Gonocerca Manter, 1925, and subfamily Gonocercinae that are based on this genus in the family Derogenidae. Also, molecular data does not support the presence of the genus Hemipera Nicoll 1913, in the subfamily Gonocercinae. The taxonomical position and species lists of representatives of the Gonocercinae need further revision.

How to cite this paper: Sokolov S.G., Gordeev I.I., Atopkin D.M. 2016. Redescription of trematode Gonocerca muraenolepisi Paruchin et Ljadov, 1979 (Hemiuroidea: Derogenidae), a body cavity parasite of Antarctic fishes, with a discussion of its phylogenetic position // Invert. Zool. Vol.13. No.2. P.191-202. doi: 10.15298/invertzool.13.2.02

KEY WORDS: trematodes, body cavity, Antarctic, the Ross Sea, the D'Urville Sea, the Amundsen Sea, 28S rDNA, Muraenolepis, Gonocerca muraenolepisi, Gonocercinae, Derogenidae.

\section{Переописание трематоды Gonocerca muraenolepisi Paruchin et Ljadov, 1979 (Hemiuroidea: Derogenidae) - паразита полости тела антарктических рыб, с обсуждением его филогенетического положения}

\author{
С.Г. Соколов ${ }^{1}$, И.И. Гордеев ${ }^{2}$, Д.М. Атопкин ${ }^{3}$
}

\footnotetext{
${ }^{1}$ Институт проблем экологии и эволючии им. А.Н. Северцова РАН, Ленинский пр. 33, Москва 119071, Россия. e-mail: sokolovsg@mail.ru

${ }^{2}$ Всероссийский научно-исследовательский институт рыбного хозяйства и океанографии, ул. Верхняя Красносельская 17, Москва 107140, Россия.

${ }^{3}$ Биолого-почвенный институт ДВО РАН, пр-т 100-летия Владивостоку 159, Владивосток 690022, Россия.
} 
РЕЗЮМЕ: Переописание Gonocerca muraenolepisi Paruchin et Ljadov, 1979 выполнено по оригинальному материалу от рыбы Muraenolepis marmorata Gınther, 1880 (Gadiformes) из моря Росса, и сохранившимся паратипам, один из которых выделен в качестве неотипа. Филогенетические связи G. muraenolepisi были изучены на основе анализа нуклеотидных последовательностей участка 28S рДНК. Молекулярные данные не согласуются с традиционной точкой зрения о членстве рода Gonocerca Manter, 1925 и, основанного на нем подсемейства Gonocercinae, в семействе Derogenidae. Также молекулярные данные не поддерживают концепцию вхождения рода Hemipera Nicoll, 1913 в состав подсемейства Gonocercinae. Таксономический статус и состав Gonocercinae требуют уточнения.

Как цитировать эту статью: Sokolov S.G., Gordeev I.I., Atopkin D.M. 2016. Redescription of trematode Gonocerca muraenolepisi Paruchin et Ljadov, 1979 (Hemiuroidea: Derogenidae), a body cavity parasite of Antarctic fishes, with a discussion of its phylogenetic position // Invert. Zool. Vol.13. No.2. P.191-202. doi: 10.15298/invertzool.13.2.02

КЛЮЧЕВЫЕ СЛОВА: трематоды, полость тела, Антарктика, море Росса, море Дюрвиля, море Амундсена, 28S рДНК, Muraenolepis, Gonocerca muraenolepisi, Gonocercinae, Derogenidae.

\section{Introduction}

The trematode Gonocerca muraenolepisi Paruchin et Ljadov, 1979 is a representative of the southern sub-polar parasitofauna of fishes. The type-host of this species marita is fish Muraenolepis marmorata Günther, 1880 (Gadiformes); the type location is the Kerguelen Islands area (Indian Ocean sector of the subAntarctic). The first description of G. muraenolepisi contains erroneous data about the site of infection of this parasite - intestine and stomach (Parukhin, Lyadov, 1979). According to Lyadov (1980) and Parukhin (1989), this species was actually found in the body cavity. In addition to M. marmorata, Lepidonotothen mizops (Günther, 1880) and Channichthys rhinoceratus Richardson, 1844 are reported hosts of G. muraenolepisi (Lyadov, 1980; Parukhin, 1989). There are no data on the distribution of this trematode outside the Kerguelen Islands area.

The parasite was found by us in M. marmorata in the Ross Sea, D'Urville Sea and Amundsen Sea. Obtained materials allow us to make sufficient additions to the species' description and to discuss its phylogenetic position.

\section{Material and methods}

\section{Sample collection}

Eighty-six individuals of M. marmorata were collected as by-catch during fishing for the Antarctic toothfish Dissostichus mawsoni Norman, 1937 in the Ross Sea from December 2011 to February 2012, and from December 2012 to January 2013; in the D'Urville Sea in February 2011; and in the Amundsen Sea in February 2015. These 86 individuals were examined for parasites. The fishing depth varied from 679 to $1480 \mathrm{~m}$. All individuals were caught using longline ('Mustad' system, auto-line, and trot-line) baited with squid. Fish identification was carried out using Fisher \& Hureau (1985). The total length of the examined fishes varied from 27 to $56 \mathrm{~cm}$.

All fishes were examined for parasitic infections using standard methods (BykhovskayaPavlovskaya, 1985). Worms were fixed in $70 \%$ ethanol under a cover glass with slight pressure, stained with acetocarmine, and mounted in Canada balsam. Drawings were made using a drawing tube. Voucher specimens studied were specimens that were deposited in the Museum of Helminthological Collections of the Centre for 
Parasitology of the A.N. Severtsov Institute of Ecology and Evolution, Moscow, Russia (IPEE RAS); inventory numbers: $1202-1216$.

The extant type material of G. muraenolepisi comprises only three paratypes deposited in the Museum of the All-Russian K.I. Skryabin Scientific Research Institute of Helminthology; inventory number: 21508 . The slide was registered in the museum by V.N. Lyadov. The species holotype mentioned in the paper of Parukhin \& Lyadov (1979) is considered as lost. Parukhin \& Lyadov (1979) wrote that the holotype was deposited in the A.O. Kovalevsky Institute of Biology of the Southern Seas (Sevastopol), named now as the A.O. Kovalevsky Institute of Marine Biological Research. However, any specimens of G. muraenolepisi are no longer in this institute (Dr Julia M. Korniychuk, personal communication). They were not in the Southern Scientific Research Institute of Marine Fisheries and Oceanography (Kerch), where V.N. Lyadov was employed, either. Based on that, we designated one of the three paratypes in slide \#21508 deposited in the All-Russian Scientific Research Institute of Helminthology as a neotype. Data on the neotype: host - Muraenolepis marmorata Günther, 1880; site of infection - the body cavity; locality - the Kerguelen Islands area (Indian Ocean sector of sub-Antarctic); collector - V.N. Lyadov. All three type specimens of $G$. muraenolepisi have more or less deformed gonads, the ovary in particular, due to overpressure during fixation.

DNA extraction, amplification and sequencing

Eleven gravid specimens of Gonocerca muraenolepisi, with body lengths of 6.7-21 mm that had been taken from M. marmorata caught in the Ross Sea and the Amundsen Sea, and were fixed in 96\% ethanol and used for molecular analysis. Total genomic DNA was extracted with an invitrogen genomic DNA extraction kit following the manufacturer's protocol. Nuclear 28S rDNA was successfully amplified using a polymerase chain reaction with the following primers: DIGL2 (5' - AAG CAT ATC ACT
AAG CGG - 3') and 1500R (5' - GCT ATC CTG AGG GAA ACT TCG - 3') (Tkach et al., 2003). Negative and positive controls using both primers were included. The PCR products were directly sequenced using an ABI Big Dye Terminator v.3.1 Cycle Sequencing Kit (Applied Biosystems, USA), as recommended by the manufacturer, with the internal sequencing primers 300F, ECD2, 900F and 1200R (Tkach, et al., 2003). The PCR products were analysed using an ABI 3130 genetic analyser at the Institute of Biology and Soil Sciences FEB RAS. The sequences have been submitted to the EMBL database with the following accession numbers: HF543941-HF543948, LN650651, LN865025, and LN865026.

\section{Sequence analysis and reconstruc-} tion of phylogeny

The ribosomal DNA sequences were assembled with SeqScape v.2.6 software and aligned using the MEGA 5.0 (Tamura et al., 2011) alignment explorer with default options. The regions that could not be unambiguously aligned were excluded from the analyses. A number of variable and parsimony-informative sites and nucleotide compositions were calculated using MEGA 5.0. Phylogenetic analysis of the nucleotide sequences was performed using Bayesian inference (BI), using MrBayes v.3.1.2 software (Huelsenbeck et al., 2001) with the general time reversible model with gamma distribution, and calculation of proportion of invariable sites $(\mathrm{GTR}+\mathrm{G}+\mathrm{I})$ (Tavare, 1986). This model showed the best fit to the data using Modeltest v.3.07 software (Posada, Crandall, 1998). A Markov chain algorithm was performed with $10,000,000$ generations. Optimisation of the Bayesian inference algorithm was performed by the setting up of priors using Tracer 1.5.0 software (Rambaut, Drummond, 2009). The significance of the phylogenetic relationship was estimated using posterior probabilities.

The phylogenetic position of G. muraenolepisi was inferred using nucleotide sequences of 28S rDNA for representatives of the superfamily Hemiuroidea and Azygioidea retrieved 
from GenBank: Accacoelium contortum (Rudolphi, 1819) [Accacoeliidae]; Derogenes varicus (Müller, 1784); Hemipera manteri (Crowcroft, 1947) [Derogenidae]; Didymozoon scombri Taschenberg, 1879 [Didymozoidae]; Bunocotyle progenetica Chabaud et Buttner, 1959; Dinurus longisinus Looss, 1907; Lecithocladium excisum (Rudolphi, 1819); Merlucciotrema praeclarum (Manter, 1934); Plerurus digitatus (Looss, 1899); Robinia aurata Pankov, Webster, Blasco-Costa, Gibson, Littlewood et Kostadinova, 2006; Saturnius sp. [Hemiuridae]; Aponurus sp., Machidatrema chilostoma (Machida, 1980) [Lecithasteridae]; Copiatestes filiferus (Leuckart in Sars, 1885) [Syncoeliidae]; Prosogonotrema bilabiatum Vigueras, 1940 [Sclerodistomidae]; and Otodistomum cestoides (van Beneden, 1871) [Azygiidae] (Olson et al., 2003; Pankov et al., 2006). Otodistomum cestoides was used as an outgroup.

\section{Results}

Fam. Derogenidae Nicoll, 1910

Subfam. Gonocercinae Skrjabin et Guschanskaja, 1955

\section{Gonocerca muraenolepisi}

Paruchin et Ljadov, 1979

Figs. 1-4. 1880.

Host. Muraenolepis marmorata Günther,

Site of infection. Body cavity.

Locality. The Ross Sea: $71^{\circ} \mathrm{S}, 177^{\circ} \mathrm{W} ; 72^{\circ}$ $\mathrm{S}, 176^{\circ} \mathrm{W} ; 77^{\circ} \mathrm{S}, 170^{\circ} \mathrm{E} ; 76^{\circ} \mathrm{S}, 170^{\circ} \mathrm{W} ; 72^{\circ} \mathrm{S}$, $175^{\circ} \mathrm{E} ; 75^{\circ} \mathrm{S}, 174^{\circ} \mathrm{E}$. The D“Urville Sea: $65^{\circ}$ $\mathrm{S}, 139^{\circ} \mathrm{E} ; 66^{\circ} \mathrm{S}, 134^{\circ} \mathrm{E}$. The Amundsen Sea: $71^{\circ}-72^{\circ} \mathrm{S} ; 118^{\circ} \mathrm{W}$.

Prevalence. All of the four examined fishes in the area bounded by the coordinates $76^{\circ} \mathrm{S}$, $170^{\circ} \mathrm{W}-77^{\circ} \mathrm{S}, 170^{\circ} \mathrm{W}$; three of the 43 examined fishes in the area bounded by the coordinates $72^{\circ} \mathrm{S}, 175^{\circ} \mathrm{E}-72^{\circ} \mathrm{S}, 176^{\circ} \mathrm{W}$; three of the nine examined fishes at coordinates $75^{\circ} \mathrm{S}$, $174^{\circ} \mathrm{E}$; five of the eight fishes at coordinates $71^{\circ} \mathrm{S}, 177^{\circ} \mathrm{W}$; two of the two fishes at coordinates $65^{\circ} \mathrm{S}, 139^{\circ} \mathrm{E}$; two of the three fishes at coordinates $66^{\circ} \mathrm{S}, 134^{\circ} \mathrm{E}$; 13 of the 25 examined fishes in in the area bounded by the coordinates $71^{\circ}-72^{\circ} \mathrm{S}, 118^{\circ} \mathrm{W}$.

Intensity. From one to 18 individuals per host.

Description (by 47 gravid specimens from the Ross Sea and three type specimens; sizes of the three type specimens are given in Table 1). Body fusiform in small specimens and foliate with conical forebody in large specimens (Figs. $1,3,4)$, its size $16.4 \pm 1.0 \times 6.8 \pm 0.5 \mathrm{~mm}$. Tegument smooth. Oral sucker subterminal, $0.579 \pm 0.021 \times 0.619 \pm 0.027 \mathrm{~mm}$; preoral lobe present; prepharynx absent; pharynx $0.290 \pm$ $0.013 \times 0.263 \pm 0.012 \mathrm{~mm}$; oesophagus short $0.304 \pm 0.020 \mathrm{~mm}$. Caeca winding, somewhat inflated, terminate near posterior extremity of body. Ventral sucker larger than oral sucker, pre-equatorial, $1.082 \pm 0.051 \times 1.090 \pm 0.048$ $\mathrm{mm}$; forebody $43.9 \pm 0.5 \%$ of body length. Oral/ ventral sucker ratio based on mean diameters $1: 1.80 \pm 0.03$; ratio based on widths $1: 1.76 \pm$ 0.03 . Testes in posterior part of body, elliptical, spherical or sub-elliptical with irregular protrusions; symmetrical or oblique (Figs. 1, 3, 4). Left testis $2.39 \pm 0.23 \times 1.96 \pm 0.16 \mathrm{~mm}$, right testis $2.42 \pm 0.22 \times 2.07 \pm 0.19 \mathrm{~mm}$; posttesticular space $12.4 \pm 0.9 \%$ of body length. Seminal vesicle tubular, usually sinuous (Fig. 2 A). Pars prostatica tubular; surrounded by sub-spherical field of dense prostatic cells, $0.307 \pm 0.024 \times 0.266 \pm 0.014 \mathrm{~mm}$. Short thinwalled ejaculatory duct opens into genital atrium (Fig. 2A). Genital atrium short, its aperture ventromedian, near posterior margin of oral sucker. Ovary between ventral sucker and testes, median, with irregular incisions (Figs. 1, 3, 4), $1.17 \pm 0.09 \times 1.13 \pm 0.09 \mathrm{~mm}$. Ootype dorsal to ovary. Laurer's canal very long, sinuous, opens dorsally between ovary and testes (their anterior edge or midlevel) (Fig. 1). Middle part of Laurer"s canal in most specimens rather dilated and filled with sperm (Fig. 1B). Two vitelline masses at ovarian level, 5-12 lobed, symmetrical or slightly oblique; in contact with testes or clearly separated from them 

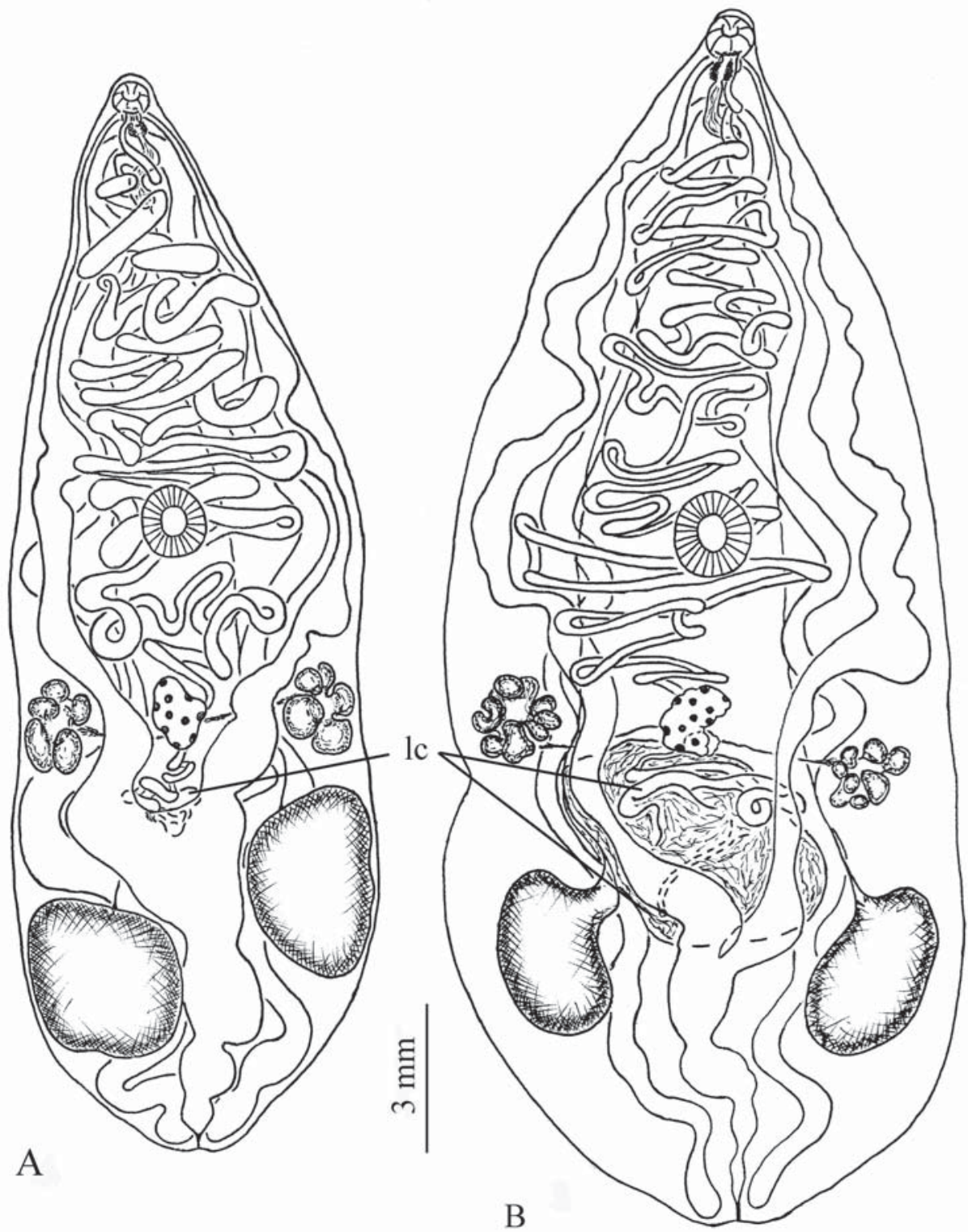

Fig. 1. Large specimens of Gonocerca muraenolepisi from body cavity of Muraenolepis marmorata caught in the Ross Sea. A - individual with Laurer's canal not filled with sperm; B — individual with Laurer"s canal filled with sperm (middle part of the canal is very extended).

Abbreviations: lc - Laurer's canal.

Рис. 1. Крупные особи Gonocerca muraenolepisi из полости тела Muraenolepis marmorata, пойманных в море Росса. А - экземпляр с Лауреровым каналом без спермы; В - экземпляр, с заполненным спермой Лауреровым каналом (средняя часть канала сильно расширена).

Обозначения: 1c - Лауреров канал. 

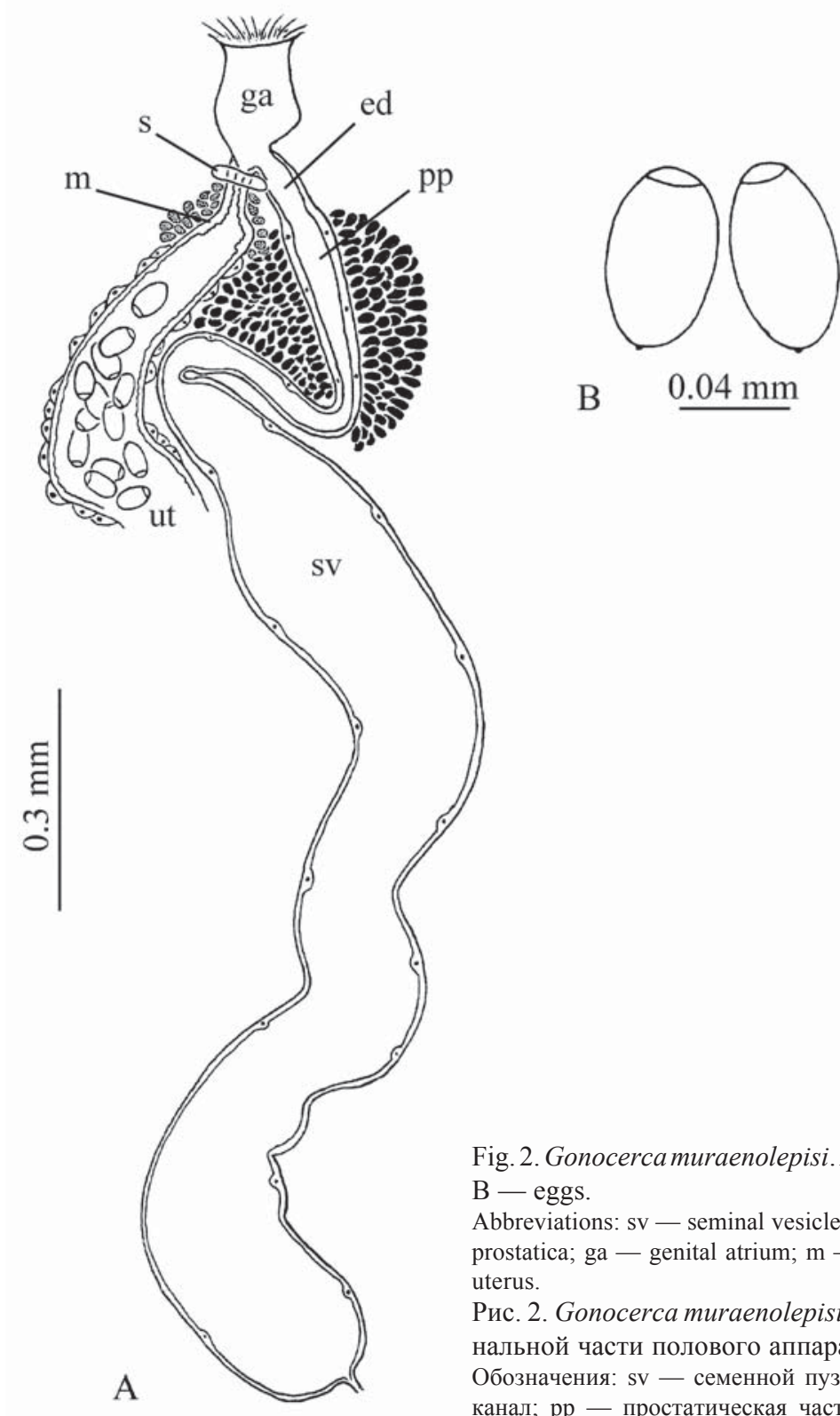

B $\quad \underline{0.04 \mathrm{~mm}}$

Fig. 2. Gonocerca muraenolepisi. A - details of terminal genitalia; $\mathrm{B}$ - eggs.

Abbreviations: sv — seminal vesicle; ed — ejaculatory duct; pp — pars prostatica; ga - genital atrium; $\mathrm{m}$ - metraterm; s — sphincter; ut uterus.

Рис. 2. Gonocerca muraenolepisi. А - детали строения терминальной части полового аппарата; В — яйца.

Обозначения: sv - семенной пузырек; ed - семяизвергательный канал; pp - простатическая часть; ga - половой атриум; m метратерм; s - сфинктер; ut - матка.

(Fig. 4). Left vitelline mass $1.48 \pm 0.14 \times 1.31 \pm$ $0.13 \mathrm{~mm}$, right mass $1.62 \pm 0.22 \times 1.37 \pm 0.16$ $\mathrm{mm}$. Uterus preovarian, transversely coiled, chiefly intracaecal (Fig. 1, 3, 4); metraterm surrounded by gland cells, terminates with sphincter (Fig. 2A). Eggs numerous, elliptical, $64 \pm 1.1 \times 33 \pm 0.6 \mu \mathrm{m}$, with operculum and small knob at anopercular pole (Fig. 2B). Excretory vesicle $\mathrm{Y}$-shaped; arms uniting dorsal to pharynx; pore terminal. 


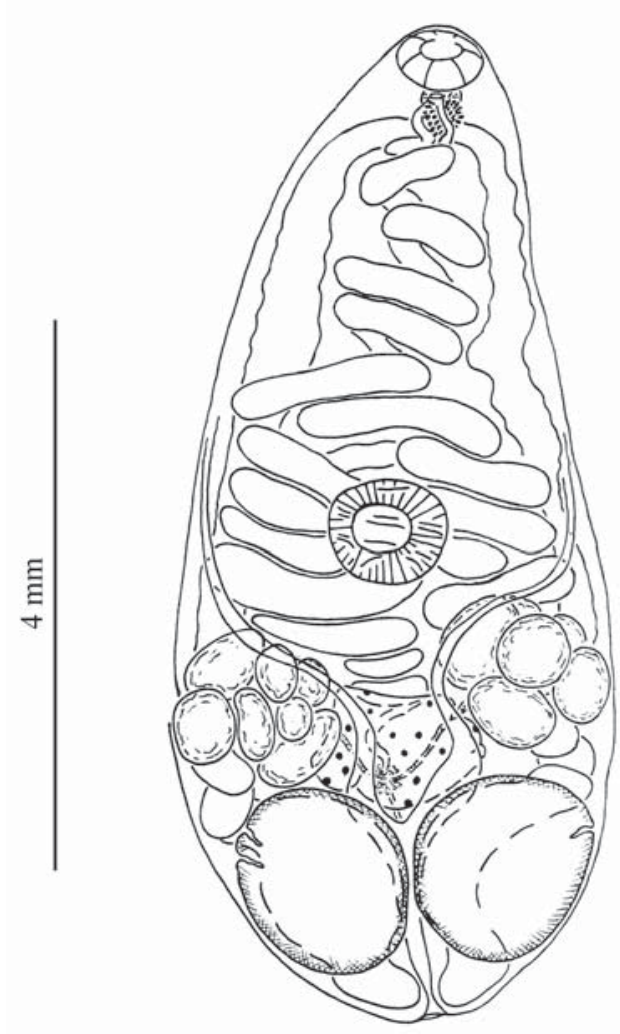

Fig. 3. Neotype of Gonocerca muraenolepisi. Slide \#21508 from the museum of helminths of the AllRussian Scientific Research Institute of Helminthology, Moscow.

Fig. 3. Неотип Gonocerca muraenolepisi. Препарат № 21508 из гельминтологического музея Всероссийского научно-исследовательского института фундаментальной и прикладной паразитологии животных и растений имени К.И. Скрябина.

\section{Phylogenetic analysis}

A 28S rDNA fragment of approximately $1300 \mathrm{bp}$ was obtained for G. muraenolepisi; the resulting sequences were presented in two variants, which have different lengths. The first one was $1164 \mathrm{bp}$ in length, and was detected for nine specimens from the Ross Sea (\#HF543941HF543948, LN650651). The second one was 1162 bp in length and was detected for two specimens from the Amundsen Sea (\#LN865025, LN865026). Overall, 11 variable sites (0.9\%) and two indels were detected between these two sequence variants. We do not make any taxonomical conclusions based on this value of genetic differentiation, because of the lack of molecular data on congeneric species of the subfamily Gonocercinae.

Bayesian inference analysis revealed the separation of the representatives of the superfamily Hemiuroidea into two main clusters (Fig. 5 I, II) and an independent branch (Fig. 5 III) that includes derogenid species $H$. manteri. The first cluster (Fig. 5 I) consists of members of the families Hemiuridae, Lecithasteridae, Accacoeliidae, Syncoeliidae, Derogenidae, Didymozoidae, and Sclerodistomidae. The second cluster (Fig. 5 II) represents species G. muraenolepisi (Derogenidae). The species Derogenes varicus (type-species of type-genus of Derogenidae) appears closely related to Didymozoon scombri (Didymozoidae), but statistical support for this connection is not high. Nevertheless, D. varicus and D. scombri are included into the large, highly supported cluster (I) that differs considerably from G. muraenolepisi and H. manteri.

\section{Discussion}

Gonocerca muraenolepisi is undoubtedly placed in the genus Gonocerca Manter, 1925 because of the post acetabular position of the ovary, the presence of two compact lateral vitelline masses at the ovarian level, the location of the testes posterior to the ovary and vitellarium, the morphology of the eggs, and the morphology of the distal part of the male and female ducts (Gibson, Bray, 1979; Gibson, 1996, 2002). At the same time, the pre-equatorial position of the ventral sucker of most studied specimens of G. muraenolepisi is not consistent with the diagnosis of the genus Gonocerca provided by Gibson \& Bray (1979) and Gibson (1996, 2002). We do not give much importance to this discrepancy. The pre-equatorial position of the ventral sucker is typical for Gonocerca lobata Byrd, 1963 and some specimens of Gonocerca caelorinchi (Machida et Kuramochi, 1994). Gibson $(1976,2002)$ recognised these species as 


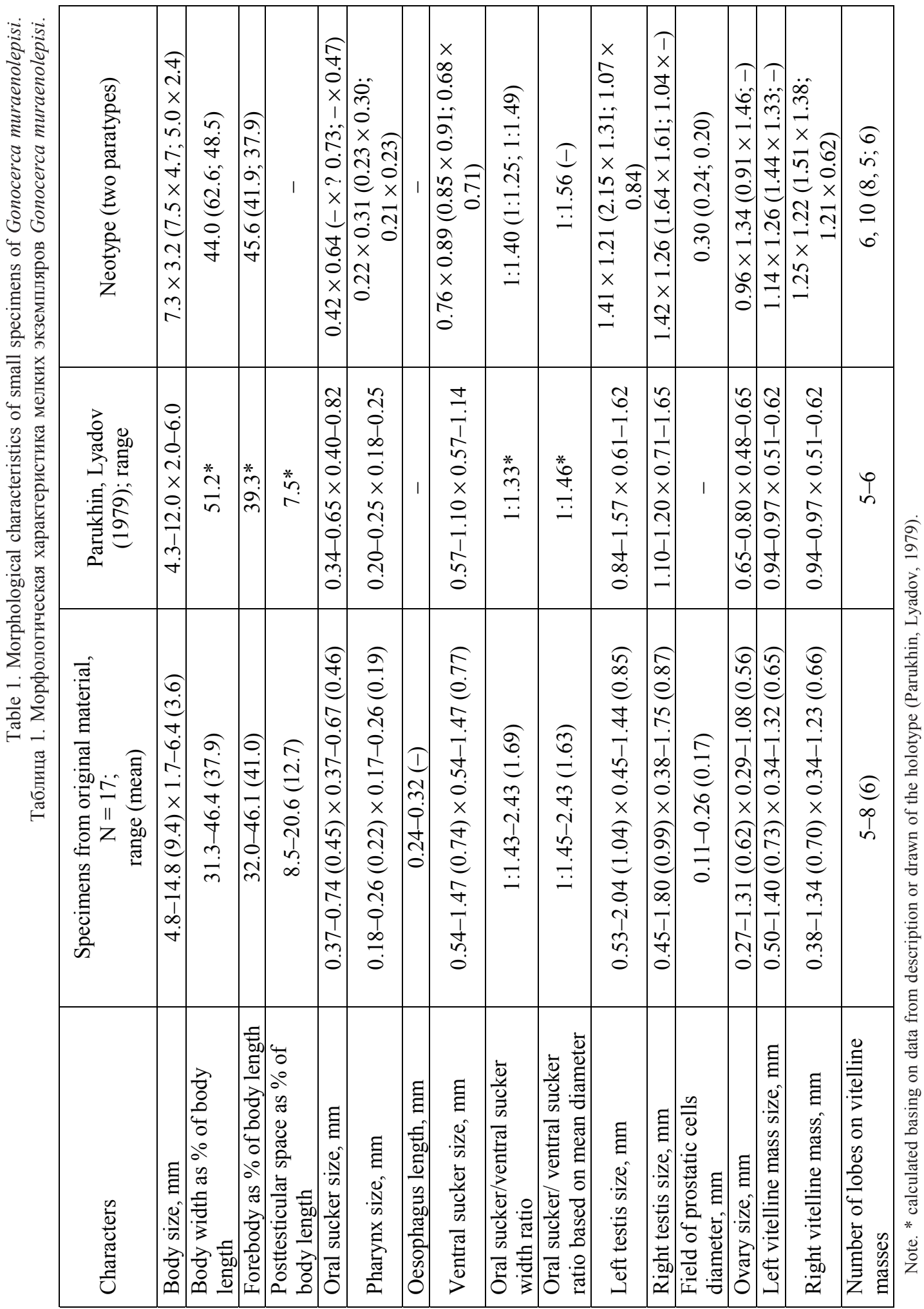




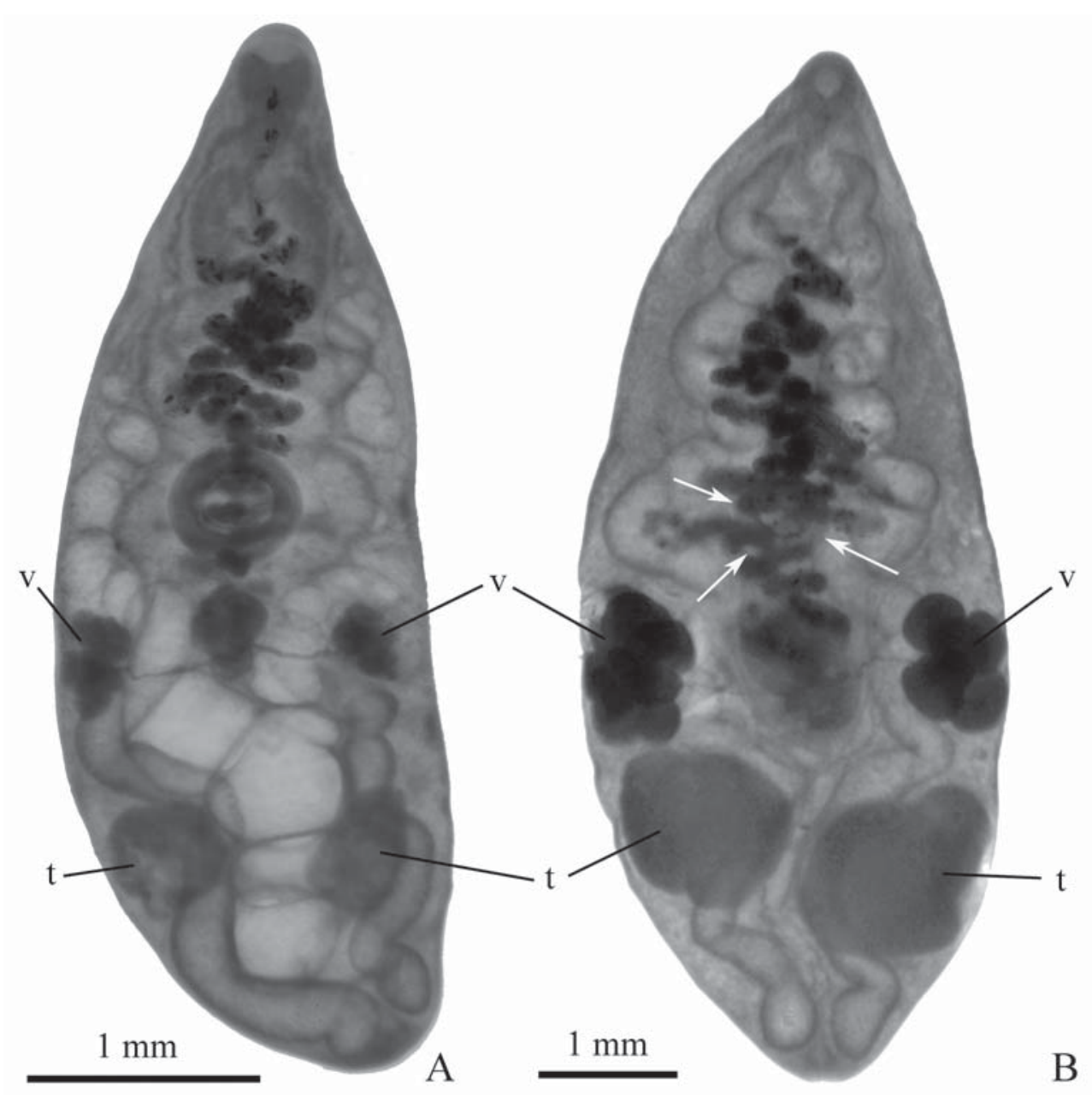

Fig. 4. Small specimens of Gonocerca muraenolepisi from body cavity of Muraenolepis marmorata caught in the Ross Sea. A, B - Examples of different remoteness of the testes from the vitelline masses. Abbreviations: $\mathrm{t}$ - testes; $\mathrm{v}$ - vitelline masses; arrows — ventral sucker.

Рис. 4. Мелкие экземпляры Gonocerca muraenolepisi из полости тела Muraenolepis marmorata, пойманных в море Росса. А, В — примеры разной удаленности семенников от желточных телец. Обозначения: $\mathrm{t}$ - семенники; $\mathrm{v}$ - желточные тельца; стрелки - брюшная присоска.

unambiguous members of the genus Gonocer$c a$.

The studied sample of trematodes contained small $(<15 \mathrm{~mm})$ and large $(\geq 15 \mathrm{~mm})$ specimens (Table 1, 2; Fig. 1, 3, 4). All specimens were mature with eggs in uterus. Analysis of $28 \mathrm{~S}$ rDNA sequences indicates that large (sample \#HF543948, body length: $17 \mathrm{~mm}$ ) and small (\#HF543941-HF543947, LN650651, body length: 6.7-14 $\mathrm{mm}$ ) specimens are conspecific. Possibly, trematodes of deep-water fishes, parasitizing in the body cavity, can live for several years, and studied specimens of different sizes have different ages. The small specimens of $G$. muraenolepisi morphologically coincide with the type-specimens of this species (Table 1).

The large specimens of G. muraenolepisi are similar to G. caelorinchi, found in the body 


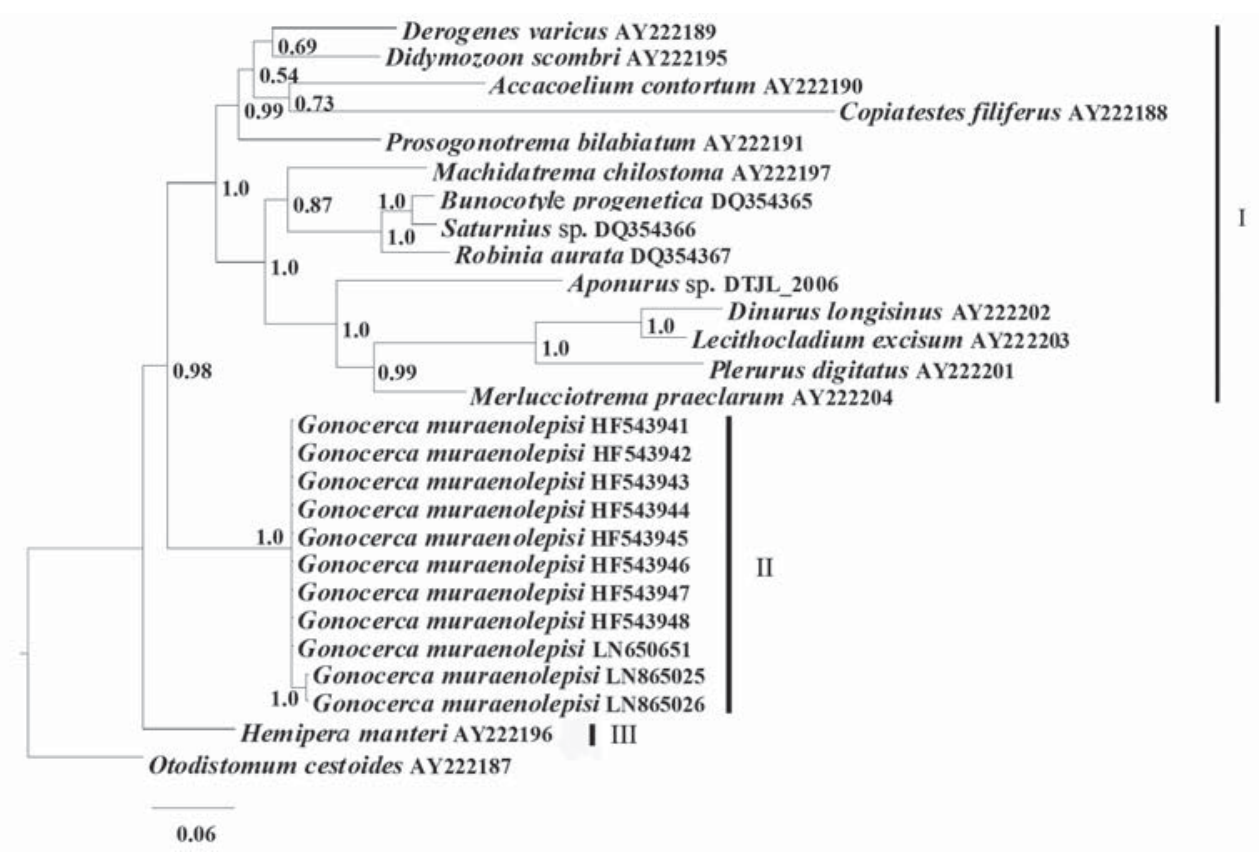

Fig. 5. Phylogenetic tree of the superfamily Hemiuroidea, reconstructed using Bayesian algorithm using $28 \mathrm{~S}$ rDNA partial sequences. Posterior probability values are given at nodes.

Рис. 5. Филогенетическое древо надсемейства Hemiuroidea, реконструированное с помощью алгоритма Байеса по данным частичного секвенирования последовательностей $28 \mathrm{~S}$ рДНК. Значения постериорных вероятностей указаны в узлах.

cavity of macrourid fish from the North Pacific (Table 2) Nevertheless, the mean value of the body width and forebody length (in both cases as a percentage of body length), the width of the pharynx, and the length and width of both suckers and diameter of the field of prostatic cells in G. muraenolepisi are lower than or equal to the minimum values for these characters in G. caelorinchi (Table 2). Clarification of the taxonomic relationships between these two species requires molecular data on G. caelorinchi.

To date, five nominal species of the genus Gonocerca: G. haedrichi Campbell et Munroe, 1977, G. lobata, G. muraenolepisi, G. phycidis Manter, 1925, G. trematomi Byrd, 1963 have been recorded from the Southern Ocean (Byrd, 1963; Gibson, 1976; Parukhin, 1989; Zdzitowiecki, 1991; Walter et al., 2002; the present study). However, some authors believe that $G$. trematomi and probably $G$. lobata should be synonymised with G. phycidis (Prudhoe, Bray, 1973; Gibson, 1976; Zdzitowiecki, 1979; Zdzitowiecki et al., 1999).
Within Hemiuroidea, the genera Gonocerca and Hemipera Nicoll, 1913 are grouped into the subfamily Gonocercinae, within the family Derogenidae, by the location of the testes which are posterior to the ovary and vitellarium (Skryabin, Gushanskaya, 1955; Yamaguti, 1971; Gibson, Bray, 1979; Gibson, 1996, 2002). The first studies on the taxonomical status of the Gonocercinae by molecular data were performed by Olson et al. (2003) and Pankov et al. (2006), using complete $18 \mathrm{~S}$ rDNA and partial $28 \mathrm{~S}$ rDNA sequences of different species of Hemiuroidea, including two derogenid species: $H$. manteri (Gonocercinae) and D. varicus (Derogeninae). Phylogenetic tree topologies, reconstructed by these authors, showed that genetic differentiation between these two species corresponded with the familial genetic divergence level of Hemiuroidea. Olson et al. (2003) and Pankov et al. (2006) suggested that the family Derogenidae is polyphyletic, and noted that the subfamily Gonocercinae can possibly be recognised as a distinct family. Our data also showed that trem- 
Redescription of trematode Gonocerca muraenolepisi (Hemiuroidea: Derogenidae) 201

Table 2. Comparative data on Gonocerca caelorinchi and large specimens of Gonocerca muraenolepisi.

Таблица 2. Сравнительные данные по Gonocerca caelorinchi и крупным особям Gonocerca muraenolepisi.

\begin{tabular}{|c|c|c|}
\hline Characters & $\begin{array}{l}\text { Gonocerca muraenolepisi, } \\
\quad \mathrm{N}=17 \text {; range (mean) }\end{array}$ & $\begin{array}{c}\text { Gonocerca caelorinchi } \\
\text { After: Machida, Kuramochi } \\
\text { (1994), Machida, Kamegai } \\
\text { (1997), N = 12; range }\end{array}$ \\
\hline Body size, mm & $\begin{array}{c}15.0-28.4(20.9) \times 5.3-10.6 \\
(7.6)\end{array}$ & $15.4-32.2 \times 5.0-12.7$ \\
\hline $\begin{array}{l}\text { Body width as \% of body } \\
\text { length }\end{array}$ & $27.8-44.1 \%(36.5 \%)$ & $52.5 \% *$ \\
\hline $\begin{array}{l}\text { Forebody as \% of body } \\
\text { length }\end{array}$ & $29.9-44.6(39.1)$ & $46.0-56.0$ \\
\hline $\begin{array}{l}\text { Posttesticular space as \% of } \\
\text { body length }\end{array}$ & $2.9-19.7(11.7)$ & $11.0-17.0$ \\
\hline Oral sucker size, mm & $\begin{array}{c}0.51-0.91(0.66) \times 0.50-0.99 \\
(0.73)\end{array}$ & $0.85-1.30 \times 0.90-1.40$ \\
\hline Pharynx size, mm & $\begin{array}{c}0.26-0.47(0.34) \times 0.23-0.38 \\
(0.31)\end{array}$ & $0.28-0.51 \times 0.37-0.57$ \\
\hline Oesophagus length, mm & $0.18-0.43(0.32)$ & to 0.40 \\
\hline Ventral sucker size, $\mathrm{mm}$ & $\begin{array}{c}0.88-1.75(1.29) \times 0.95-1.64 \\
(1.29)\end{array}$ & $1.45-2.00 \times 1.45-2.15$ \\
\hline $\begin{array}{l}\text { Oral sucker/ venral sucker } \\
\text { width ratio }\end{array}$ & $1: 1.46-2.22(1.78)$ & \multirow[b]{2}{*}{$1: 1.40-1.80 * *$} \\
\hline $\begin{array}{l}\text { Oral sucker/ ventral sucker } \\
\text { ratio based on mean } \\
\text { diameter }\end{array}$ & $1: 1.63-2.24(1.87)$ & \\
\hline Left testis size, $\mathrm{mm}$ & $\begin{array}{c}1.27-3.78(2.76) \times 1.52-2.61 \\
(2.27)\end{array}$ & $0.70-2.55 \times 1.05-2.95$ \\
\hline Right testis size, $\mathrm{mm}$ & $\begin{array}{c}1.67-3.70(2.81) \times 1.23-3.19 \\
(2.40)\end{array}$ & $1.25-2.85 \times 0.85-3.50$ \\
\hline $\begin{array}{l}\text { Field of prostatic cells } \\
\text { diameter, mm }\end{array}$ & $0.24-0.42(0.31)$ & $0.31-0.56$ \\
\hline Ovary size, $\mathrm{mm}$ & $\begin{array}{c}0.75-1.57(1.31) \times 0.85-1.50 \\
(1.28)\end{array}$ & $0.60-1.30 \times 0.75-1.65$ \\
\hline Left vitelline mass size, $\mathrm{mm}$ & $\begin{array}{c}0.92-2.68(1.69) \times 1.00-2.47 \\
(1.49)\end{array}$ & $0.92-2.10 \times 1.20-2.10$ \\
\hline Right vitelline mass, mm & $\begin{array}{c}0.84-4.22(1.89) \times 0.96-2.88 \\
(1.58)\end{array}$ & $1.05-1.85 \times 1.25-2.25$ \\
\hline $\begin{array}{l}\text { Number of lobes on vitelline } \\
\text { masses }\end{array}$ & $5-12(8)$ & $3-8$ \\
\hline Eggs size, $\mu \mathrm{m}$ & $57-72(63) \times 31-39(34)$ & $47-68 \times 28-39$ \\
\hline
\end{tabular}

Note. * calculated by the figure of Machida, Kuramochi (1994); ** options of oral/ventral suckers ratio (width or mean diameter) were not specified. 
atodes of the family Derogenidae do not form a single phylogenetic cluster, indicating polyphyly of this taxon. Nevertheless, we consider the discussion of the Gonocercinae's taxonomical status premature. Genetic study of the typespecies of the genus Gonocerca - G. phycidis is needed for an adequate decision on this question. Moreover, we cannot integrate G. muraenolepisi and $H$. manteri into the one subfamily based on the molecularly-based analysis of phylogenetic relationships (Fig. 5). Therefore, genus Hemipera belonging to the subfamily Gonocercinae needs confirmation.

\section{Acknowledgements}

The authors are deeply grateful to A. Kostadinova for help on preparing of this paper, to R. Salamatin, A. Rocka, W. Jeżewski, D. Gibson and R. Bray for help in searching the literature. The work was partly supported by the RFBR \#\# 14-04-31950 and 15-29-02528.

\section{References}

Bykhovskaya-Pavlovskaya I.E. 1985. [Parasites of fishes]. Leningrad: Nauka. 121 p. [in Russian]

Byrd M.A. 1963. Helminth Parasites of Antarctic Vertebrates. Part I. Digenetic Trematodes of Marine Fishes // Proceedings of the Helminthological Society of Washington. Vol.30. No.1. P.129-148.

Fisher W., Hureau J.-C. (eds.). 1985. FAO Species identification sheets for fishery purposes. South Ocean: fishing areas 48, 58 and 88 (CCAMLR convention area). Roma: FAO. Vol.2. P.235-479.

Gibson D.I. 1976. Monogenea and Digenea from fishes // Discov. rep. Vol.36. P.179-266.

Gibson D.I. 1996. Trematoda // L. Margolis, Z. Kabata (eds.). Guide to the parasites of fishes of Canada. Ottawa: NRC Research Press. Vol.4. 373 p.

Gibson D.I. 2002. Family Derogenidae Nicoll, 1910 // D.I. Gibson, A. Jones, R.A. Bray (eds.). Keys to the Trematoda. Wallingford: CAB International. T.1. P.351368.

Gibson D.I., Bray R.A. 1979.The Hemiuroidea: terminology, systematics and evolution // Bull. br. Mus. nat. Hist. Zool. Vol.36. P.35-146.

Huelsenbeck J.P., Ronquist F., Nielsen R., Bollback J.P. 2001. Bayesian inference of phylogeny and its impact on evolutionary biology // Science. Vol.294. No.5550. P.2310-2314

Lyadov V.N. 1980. [Parasitic worms and crustaceous of commercial fishes of the Indian sector of the Antarctic (Kergelen area)]. PhD Dissertation. Moscow: VIGIS. 151 p. [in Russian]

Machida M., Kamegai S. 1997. Digenean trematodes from deep-sea fishes of Suruga Bay, Central Japan // National Science Museum monographs. Vol.12. P.19-30.

Machida M., Kuramochi T. 1994. Two new species of trematodes (Gorgoderidae and Lepocreadiidae) from deep-sea fishes of Suruga Bay, Japan // Bull. Natl. Sci. Mus. Ser. A (Japan). Vol.20. P.149-153.

Olson P.D., Cribb T.H., Tkach V.V., Bray R.A., Littlewood D.T. J. 2003. Phylogeny and classification of the Digenea (Platyhelminthes: Trematoda) // Int. J. Parasitol. Vol.33. No.7. P.733-755.

Pankov P., Webster B.L., Blasco-Costa I., Gibson D.I., Littlewood D.T.J., Balbuena J.A., Kostadinova A. 2006. Robinia aurata n. g., n. sp. (Digenea: Hemiuridae) from the mugilid Liza aurata with a molecular confirmation of its position within the Hemiuroidea // Parasitology. Vol.133. No.2. P.217-227.

Parukhin A.M. 1989. [Parasitic worms of bottom fishes of southern seas]. Kiev: Naukova Dumka. 156 p. [in Russian]

Parukhin A.M., Lyadov V.N. 1979. [New genus and species of trematodes, fish parasites in the Subantarctic zone of the Indian Ocean] // Zool. Zhurn. Vol.58. P.637-642 [in Russian].

Posada D., Crandall K. 1998. Modeltest: testing the model of DNA substitution // Bioinformatics. Vol.14. No.9. P.817-818.

Prudhoe S., Bray R.A. 1973. Digenetic trematodes from fishes // Reports B.A.N.Z. Antarctic Research Expedition. Ser.B. Vol.8. P.195-225.

Rambaut A., Drummond A. 2009. Tracer version 1.5.0. 2009. Available from http://beast.bio.ed.ac.uk (accessed 29 May 2013).

Skryabin K.I., Gushanskaya L Kh. 1955. [Suborder Hemiurata (Markevitsch, 1951) Skrjabin et Gushanskaja, 1954. Part 3] // K.I. Skryabin (ed.). Trematody zhivotnykh i cheloveka. Moscow: Publishing House of the USSR Academic Sciense. T.11. P.465-748 [in Russian].

Tamura K., Peterson D., Peterson N., Stecher G., Nei M., Kumar S. 2011. MEGA5: Molecular evolutionary genetics analysis using maximum likelihood, evolutionary distance and maximum parsimony methods // Mol. Biol. Evol. Vol.28. No.10. P.2731-2739.

Tavare S. 1986. Some probablistic and statistical problems on the analysis of DNA sequences // Lectures Math. Life Sci. Vol.17. P.57-86.

Tkach V.V., Littlewood D.T.J., Olson P.D., Kinsella J.M., Swiderski Z. 2003. Molecular phylogenetic analysis of the Microphalloidea Ward, 1901 (Trematoda: Digenea) // Syst. Parasitol. Vol.56. No.1. P.1-15.

Walter T., Palm H.W., Piepiorka S., Rueckert S. 2002. Parasites of the Antarctic rattail Macrourus whitsoni Regan, 1913 (Macrouridae, Gadiformes) // Polar Biol. Vol.25. No.9. P.633-640.

Yamaguti S. 1971. Synopsis of digenetic trematodes of vertebrates. Tokyo: Keigaku. T.1.1074 p.

Zdzitowiecki K. 1979. Digenetic trematodes in alimentary tracts of fishes of South Georgia and South Shetland (Antarctica)// Acta Ichthyol. Pisc. Vol.9. No.1. P.15-31.

Zdzitowiecki K. 1991. Occurrence of digeneans in open sea fishes off the South Shetland Islands and South Georgia, and a list of fish digeneans in the Antarctic // Pol. Polar Res. Vol.12. No.1. P.55-72.

Zdzitowiecki K., Palladino S., Vacchi M. 1999. Preliminary results on Digenea found in fishes in the coastal waters of Terra Nova Bay, Antarctica // Parassitologia. Vol.41. No.1. P.575-578.

Responsible editor E.N. Temereva 